\title{
Intracellular Sodium in Macula Densa Cells and Renin Release
}

\author{
V. S. Sottiurai, M.D., Ph.D.,' and Richard Malvin, Ph.D. \\ Department of Surgery and Department of Physiology, University of Michigan. Ann Arbor, Michigan \\ Presented at the Annual Meeting of the Association for Academic Surgery, Chicago, Illinois, \\ November 8-11, 1981
}

It is well established that two microanatomical areas of the kidney (macula densa and juxtaglomerular cells) are in some way associated with the secretion of renin. However, their precise role in the regulation of this hormone remains unresolved. Controversy still exists as to whether the rate of renin secretion is controlled solely by a pressure and stretch sensitive receptor in the juxtaglomerular cells $[1,9,10]$, by some function of sodium delivery to the macula densa cells [11], or both [5]. However, the macula densa theory has a greater number of proponents.

Macula densa cells have been reported to contain cilia and may be capable of detecting physical stimuli [6]. Physically, the macula densa cells are in direct contact with the afferent and efferent arterioles and the polkissen cells. Although macula densa cells have long been implicated in the regulation of renin secretion, to date, there has been no reported evidence that intracellular sodium concentrations correlate with the plasma renin activity.

Because the juxtaglomerular apparatus is situated deep in the renal cortex, it is inaccessible to micropuncture and direct study of these cells in situ. The present investigation was undertaken to: (i) devise a technique to quantitate the concentration of intracellular sodium of the macula densa cells, and (ii) determine whether the intracellular

\footnotetext{
'Address reprint requests to V. S. Sottiurai, M.D., Ph.D., Department of Surgery, Louisiana State University, School of Medicine, 1542 Tulane Avenue, New Orleans, La. 70112.
}

sodium concentration correlates with the plasma renin activity.

\section{MATERIALS AND METHODS}

\section{Diet Experiment}

A. Low sodium diet (10 mEquiv $\mathrm{Na} /$ day) of H/D dog food (Riviana Food, Inc., Topeka, Kansas) was given to three adult male mongrel dogs for 2-21 days until the plasma renin activity (PRA) was increased several times the base line. Surgical procedures were performed following $16 \mathrm{hr}$ of fasting. After intravenous pentobarbital anesthesia $(30 \mathrm{mg} / \mathrm{kg})$, the femoral artery and vein were catheterized for blood pressure monitoring, blood samples, and saline infusion called for by the protocol. One hour following surgery, two arterial blood samples for determination of PRA were collected. PRA was measured by radioimmunoassay using the New England Nuclear Kit for angiotensin I generation. Concomitantly, an open renal wedge biopsy (approximately 2 $\times 8 \mathrm{~mm}$ ) was taken through a standard flank nephrectomy incision. Hemostasis was maintained with gentle pressure. Additional arterial samples and renal biopsies were taken $1 \mathrm{hr}$ following saline infusion $(25 \mathrm{ml} / \mathrm{min}$ for a total of $500 \mathrm{ml}$ ).

B. High sodium diet ( 100 mEquiv $\mathrm{Na}$ / day). Two male mongrel dogs were placed on this diet for 1 week to deplete renin in the juxtaglomerular cells and reduce PRA. Arterial blood samples and open renal wedge biopsies were obtained $1 \mathrm{hr}$ before and after saline loading. 


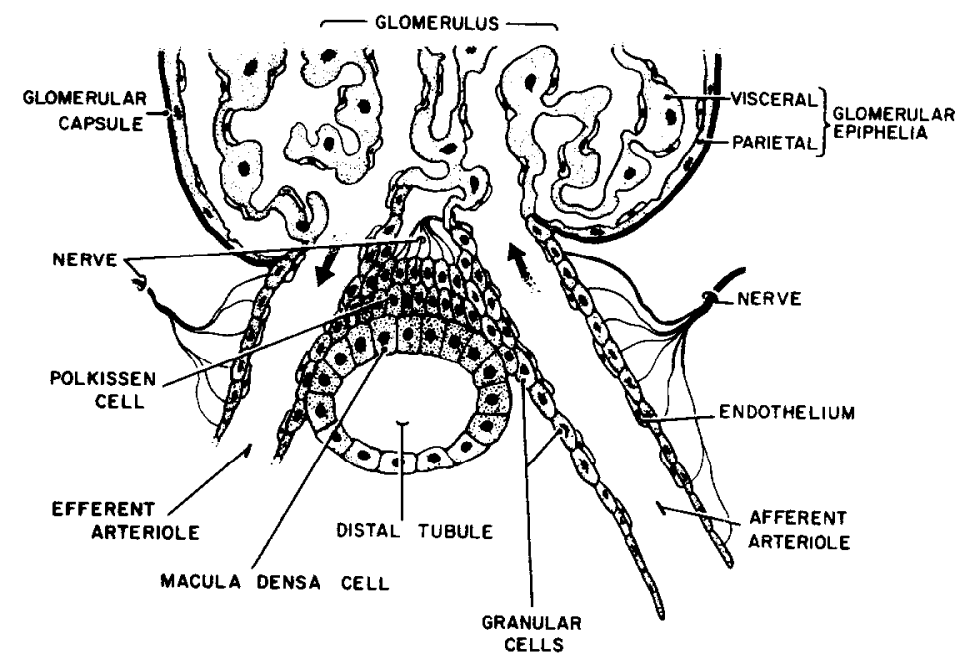

FiG. 1. Diagram of the juxtaglomerular apparatus of dog kidney.

\section{Hemorrhage Experiment}

Four dogs placed on high sodium diets (100 mEquiv $\mathrm{Na} /$ day) to suppress renin secretion were hemorrhaged for $20 \%$ of the estimated blood volume via the femoral artery catheter. Autotransfusion took place 60 min following hemorrhage. Arterial blood samples for immunoassay of renin and open wedge biopsy were taken $60 \mathrm{~min}$ before and after hemorrhage, and $60 \mathrm{~min}$ after autotransfusion.

\section{Abdominal Aortic Coarctation Experiment}

Suprarenal abdominal aortic coarctation was created with an adjustable clamp through a transabdominal approach. Mean arterial pressure distal to the clamp was maintained at $60-80 \mathrm{~mm} \mathrm{Hg}$ by tightening the clamp. Arterial blood samples for renin immunoassay and open renal wedge biopsies were obtained $60 \mathrm{~min}$ before and after aortic coarctation, and $60 \mathrm{~min}$ following removal of the aortic clamp.

\section{Electron Microprobe Analysis}

Cortical tissues from renal biopsies were immediately diced into $1 \mathrm{~mm}^{3}$ while being fixed by immersion for $3 \mathrm{hr}$ in phosphatebuffered $2 \%$ glutaraldehyde and $2 \%$ potas- sium pyroantimmoniate The latter compound is known to bind and precipitate sodium [4]. The osmolality of the fixative was adjusted to $300 \mathrm{MOsM} / \mathrm{kg} \mathrm{H}_{2} \mathrm{O}$ with sucrose. Following dehydration in ethanol, the tissues were embedded in sodium free Vestapal. Sections $1 \mu \mathrm{m}$ thick were mounted on specially prepared Vestapal plates and stained with toluidine blue. Under a dissecting microscope, macula densa cells were dissected free from the surrounding tissues to facilitate sodium quantitation in macula densa cells with an electron microprobe. Tissue samples and biological standard [7] were coated with approximately $500 \AA$ of aluminum to prevent the buildup of electron charges and minimize beam heating effects in the microprobe. Coating tissue samples and the biological standard simultaneously ensured an equal thickness of aluminum coating on all preparations. Intracellular sodium of each macula densa cell at the luminal, basal, and lateral areas of the nucleus was quantitated with $1 \mu \mathrm{m}$ beam diameter. The depth of the beam penetration was also set at $1 \mu \mathrm{m}$. Aluminum counts monitored on a separate spectrometer as the beam penetrated the tissue was used to determine proper depth of beam penetration. As soon as the beam penetrated to a depth greater 

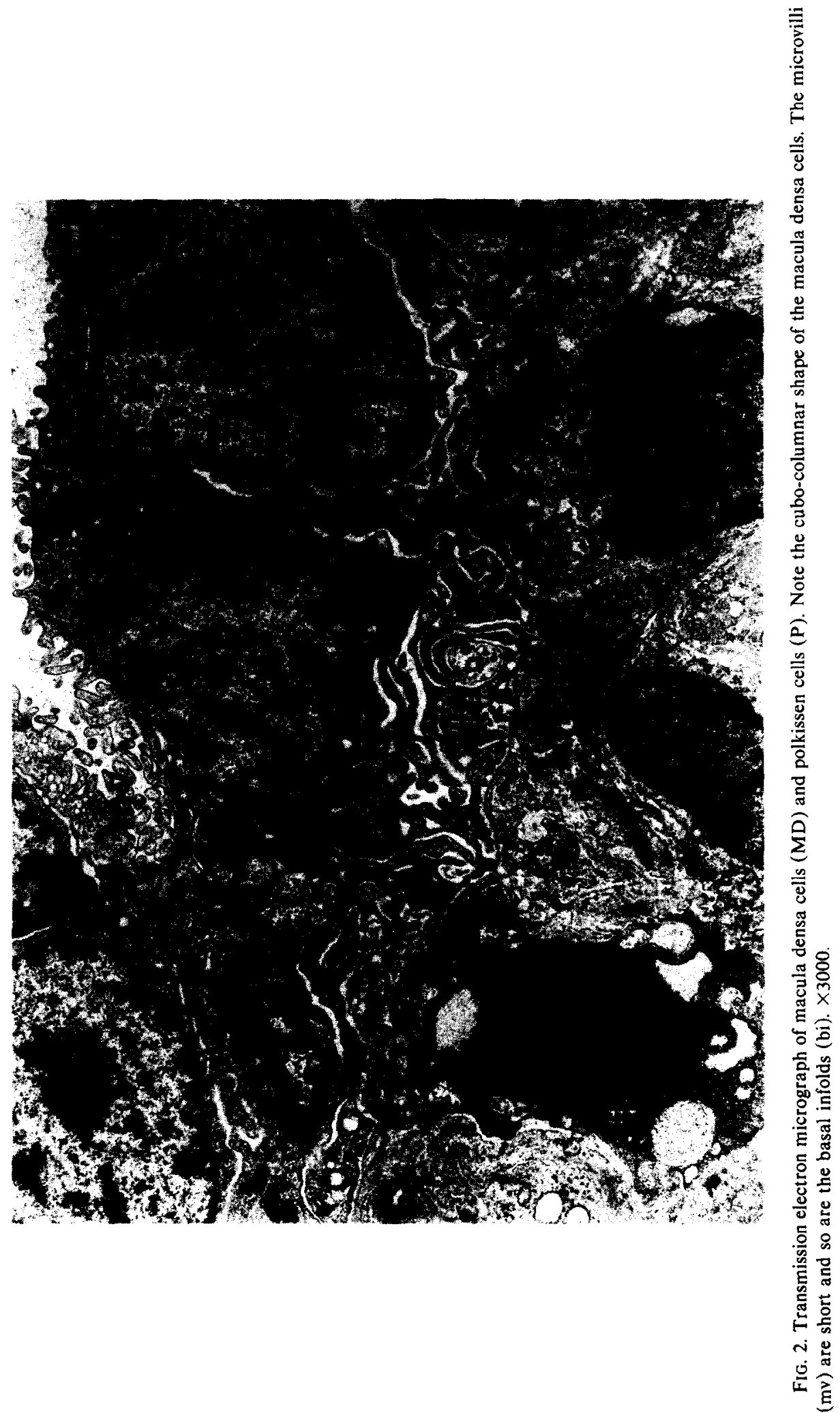


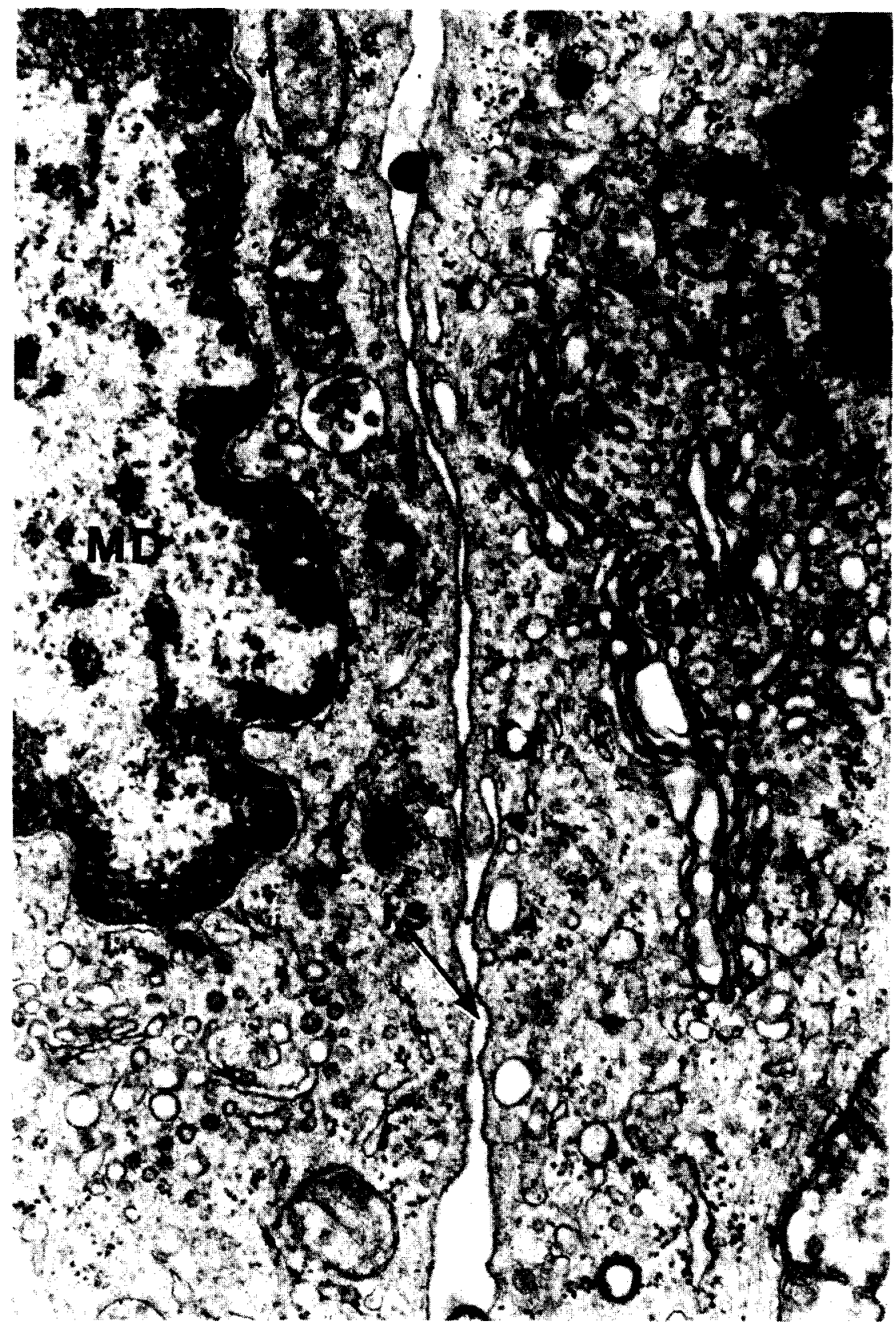

FIG. 3. Transmission electron micrograph depicting two macula densa cells (MD) lying side by side. Golgi complexes ( $\mathrm{gc}$ ) and rough endoplasmic reticulum are frequently found at the lateral aspects of the macula densa cells. Intercellular space (is), mitochondria (m). $\times 30,000$.

than the depth of the tissue $(1 \mu \mathrm{m})$, the aluminum counts increased sharply. The beam was then backed up until the aluminum counts were reduced to near zero. Both the standard and tissue samples were counted for sodium at the same beam setting. This method has been previously described [7].

\section{RESULTS}

The juxtaglomerular apparatus of the kidney is located at the hilium of the glomerulus consisting of three components: (i) the macula densa of the distal tubule, (ii) the granular epithelioid cell or juxtaglomerular cell, 
TABLE 1

Comparison of Intracellular Na in Differing Areas of Macula Densa Cells IN Low Na DIET STUDY

\begin{tabular}{lccccc}
\hline $\begin{array}{c}\text { Experimental } \\
\text { condition } \\
(n=3)\end{array}$ & $\begin{array}{c}\text { Cells/ } \\
\text { glomeruli }\end{array}$ & $\begin{array}{c}\text { Luminal } \\
([\mathrm{Na}] \mathrm{mEquiv} / \mathrm{kg})\end{array}$ & $\begin{array}{c}\text { Basal } \\
([\mathrm{Na}] \mathrm{mEquiv} / \mathrm{kg})\end{array}$ & $\begin{array}{c}\text { R. Lateral } \\
([\mathrm{Na}] \mathrm{mEquiv} / \mathrm{kg})\end{array}$ & $\begin{array}{c}\text { L. Lateral } \\
([\mathrm{Na}] \mathrm{mEquiv} / \mathrm{kg})\end{array}$ \\
\hline Low Na diet & $59 / 15$ & $10.4 \pm 1.0$ & $9.8 \pm 0.8$ & $10.1 \pm 0.8$ & $9.6 \pm 0.9$ \\
Saline infusion & $45 / 13$ & $9.2 \pm 0.8$ & $9.8 \pm 0.7$ & $10.9 \pm 0.5$ & $10.4 \pm 0.6$ \\
\hline
\end{tabular}

found closely associated with the terminal portion of the afferent and probably the efferent arteriole, and (iii) a group of cells surrounded by the macula densa, the glomerulus, the afferent, and efferent arterioles. They are the polkissen cells of Zimmerman, also known as the pseudo-Meissnerian cells of Goormaghtith, the agranular epithelioid cell, the Lacis cell, and the extraglomerular mesangial cells. This group of cells is intimately in contact with the macula densa, the mesangial cells of the glomerulus, and the granular cells of the arterioles (Figs. 1 and 2). Macula densa cells are modified epithelial cells of the distal renal tubule that are apposed to the polkissen cells at the hilium of the glomerulus. They are cuboid-columnar epithelial cells with round-ovoid nuclci. The basal infolds are short as are the microvilli. Mitochondria, rough endoplasmic reticulum, ribosomes, and Golgi complexes are found distributed throughout the cytoplasm of the cells, particularly at the lateral aspect (Fig. 3).

Table 1 compares sodium concentration at the luminal, basal, and lateral areas of the macula densa cells in dogs with elevated plasma renin activity following manipulation of sodium intake. Independent of the plasma renin activity, intracellular sodium concen- tration remained the same throughout the macula densa cells. Infusion of saline, although reducing PRA significantly, did not alter the cellular concentration of sodium. In both situations intracellular sodium averaged approximately $10 \mathrm{mEquiv} / \mathrm{kg}$ cell.

Tables 2 and 3 display similar sodium concentrations in the macula densa cells during high and low plasma renin activity resulting from different sodium diets, hemorrhage, and aortic coarctation. There was no identifiable direct correlation between plasma renin activity and intracellular sodium concentrations.

Figures 4 and 5 demonstrate the distribution of sodium pyroantimmoniate granules along the basal lamina and the interstitial space of the macula densa cells. In contradistinction to the collapsed interstitium in renal epithelia that is frequently reported in the literature, dilated interstitial spaces were present in kidneys subjected to perfusion fixation at physiological pressure (Fig. 6).

\section{DISCUSSION}

Despite extensive research concerning renin-angiotensin how renin is synthesized and what triggers its release remain contro-

TABLE 2

Correlation of PRA and Intramacula Densa Na Concentration in Na Diet Study

\begin{tabular}{lccccc}
\hline $\begin{array}{l}\text { Experimental } \\
\text { condition }\end{array}$ & $\begin{array}{c}\text { No. of } \\
\text { dogs }\end{array}$ & $\begin{array}{c}\text { Glomeruli } \\
\text { counted }\end{array}$ & $\begin{array}{c}\text { M.D. cells } \\
\text { counted }\end{array}$ & $\begin{array}{c}\text { NA in M.D. } \\
\text { ([Na] mEquiv/kg) }\end{array}$ & $\begin{array}{c}\text { PRA } \\
(\mathrm{ng} / \mathrm{ml} \cdot \mathrm{H})\end{array}$ \\
\hline Low Na diet & 3 & 21 & 70 & $10.0 \pm 0.8$ & $7.6 \pm 0.2$ \\
Saline infusion & 18 & 57 & $10.1 \pm 0.9$ & $1.0 \pm 0.2$ \\
\hline
\end{tabular}




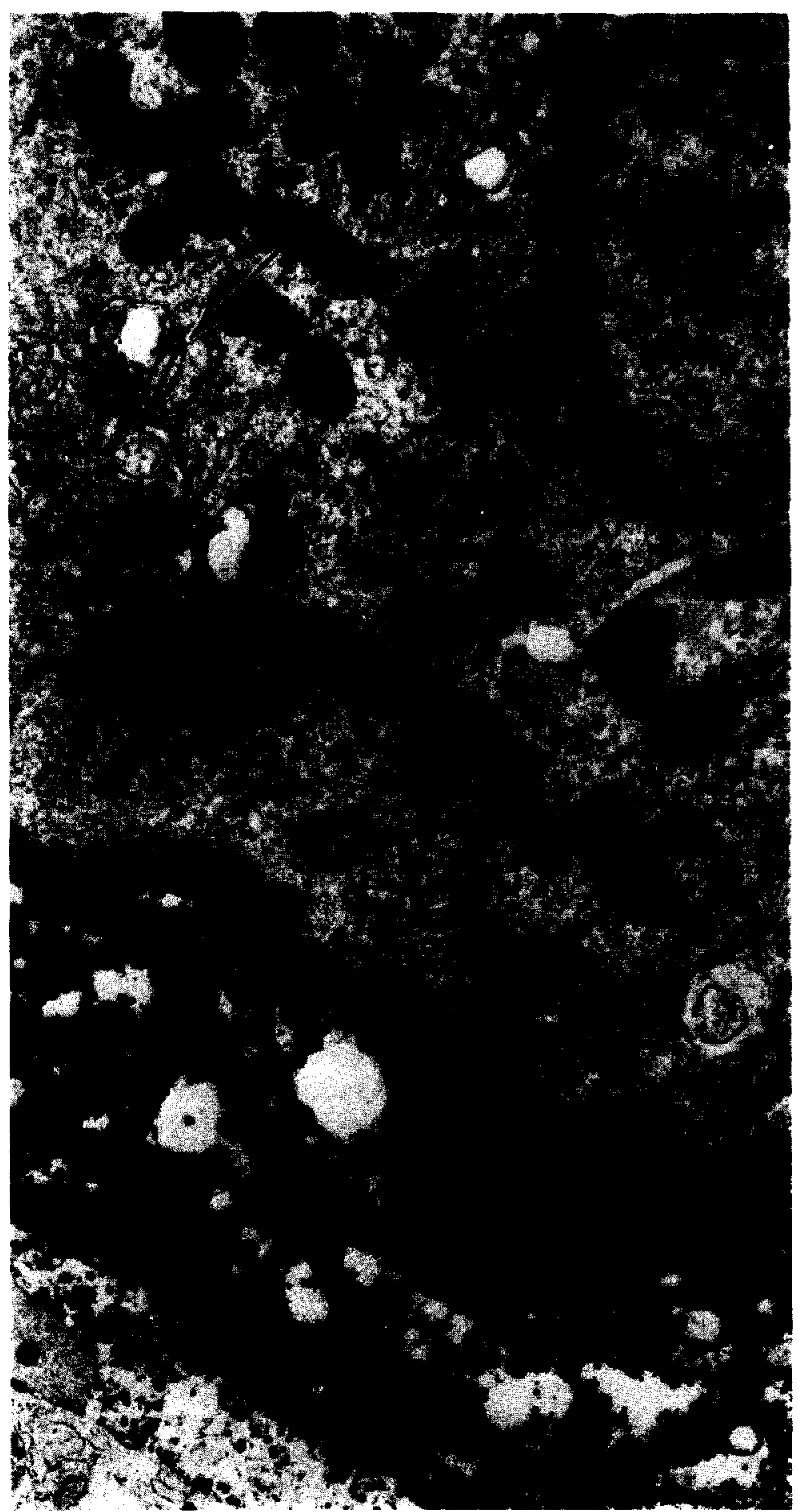

FIG. 4. Transmission electron micrograph of macula densa cells (MD) and the distribution of sodium pryoantimmoniate granules (arrows). Sodium pryoantimmoniate granules are found predominantly along the basal lamina, the basal infolds, and the interstitial space. Golgi complexes ( $\mathrm{gc}$ ), mitochondria $(\mathrm{m}$ ). $\times 10,000$. 


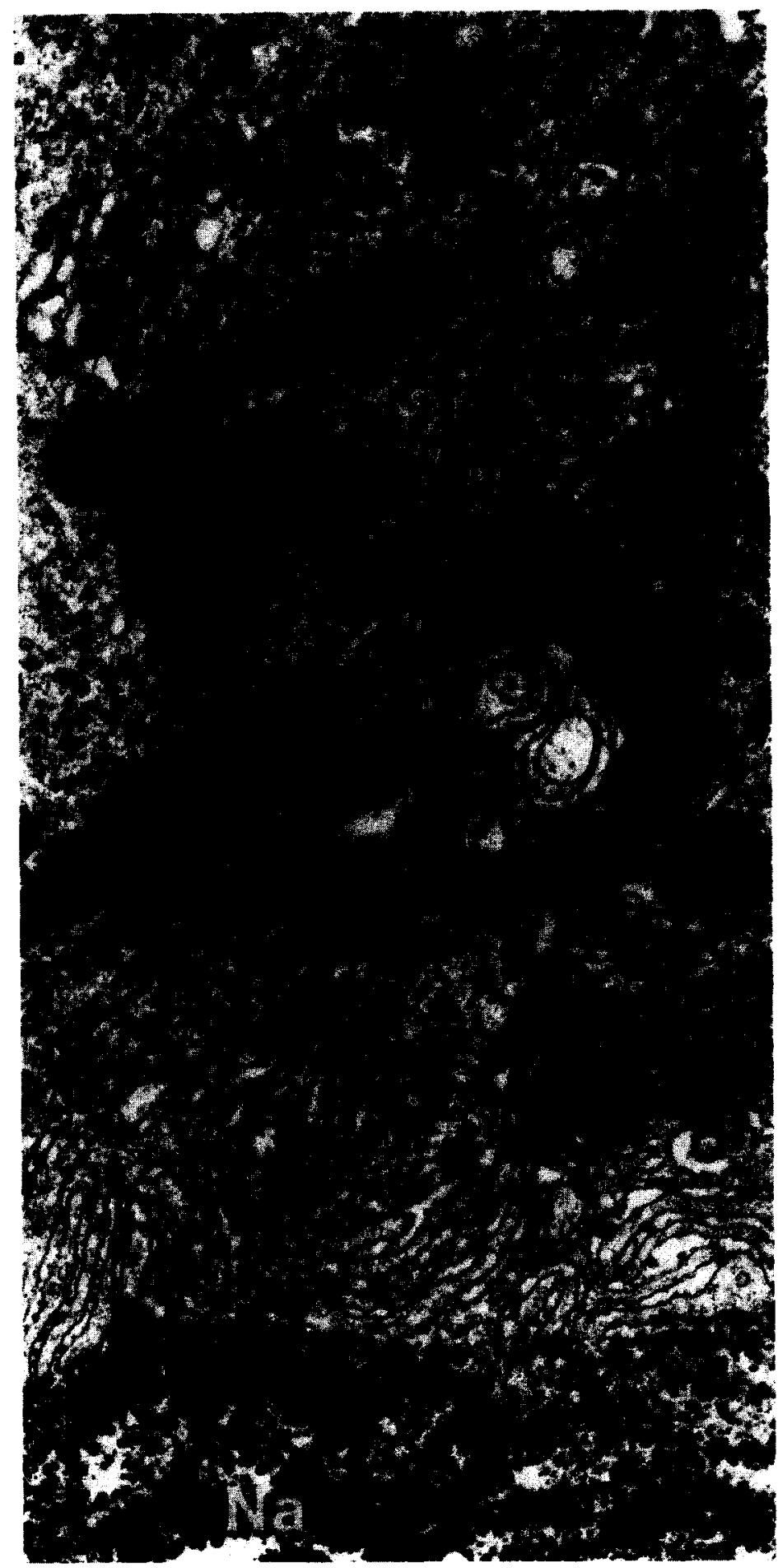

FIG. 5. Transmission electron micrograph demonstrating the distribution of electron-dense sodium pryoantimmoniate (arrow) throughout the macula densa cells. Double arrows indicate basal infolds, single arrow indicates intercellular space. Golgi complexes $(\mathrm{gc})$, mitochondria (m). Abundant sodium pryoantimmoniate is found along the basal lamina, basal infolds, and intercellular space. $\times 15,000$. 
TABLE 3

Correlation of PRA and Intramacula Densa Na Concentration following Hemorrhage and AOrTIC Coarctation

\begin{tabular}{lccccr}
\hline $\begin{array}{c}\text { Experimental } \\
\text { condition }\end{array}$ & $\begin{array}{c}\text { No. of } \\
\text { dogs }\end{array}$ & $\begin{array}{c}\text { Glomeruli } \\
\text { counted }\end{array}$ & $\begin{array}{c}\text { M.D. cells } \\
\text { counted }\end{array}$ & $\begin{array}{c}\text { Na in M.D. } \\
([\mathrm{Na}] \mathrm{mEquiv} / \mathrm{kg})\end{array}$ & $\begin{array}{r}\text { PRA } \\
(\mathrm{ng} / \mathrm{ml} \cdot \mathrm{H})\end{array}$ \\
\hline Control & 4 & 24 & 82 & $10.6 \pm 0.9$ & $3.7 \pm 0.2$ \\
Hemorrhage & & 21 & 64 & $11.0 \pm 0.9$ & $19.0 \pm 0.6$ \\
Autotransfusion & & 26 & 73 & $10.6 \pm 0.8$ & $6.4 \pm 0.6$ \\
Control & 4 & 18 & 69 & $10.1 \pm 1.3$ & $3.0 \pm 0.1$ \\
Aortic coarctation & & 23 & 75 & $10.2 \pm 1.2$ & $10.0 \pm 0.3$ \\
Release coarctation & & 22 & 71 & $10.3 \pm 1.0$ & $2.9 \pm 0.2$ \\
\hline
\end{tabular}

versial. It is generally agreed that the juxtaglomerular apparatus of the kidney is associated with renin synthesis and release $[1$, 8-10]. However, the precise role in the regulation of this hormone is unknown. Controversy still exists as to whether the rate of renin secretion is controlled by a pressure or stretch sensitive receptor in the juxtaglomerular cell—baroreceptor theory $[1,9,10]$, or by some function of sodium delivery to the macula densa cells-macula densa theory [11]. The latter appears to have a greater number of proponents. The juxtaglomerular apparatus is located deep in the cortex which

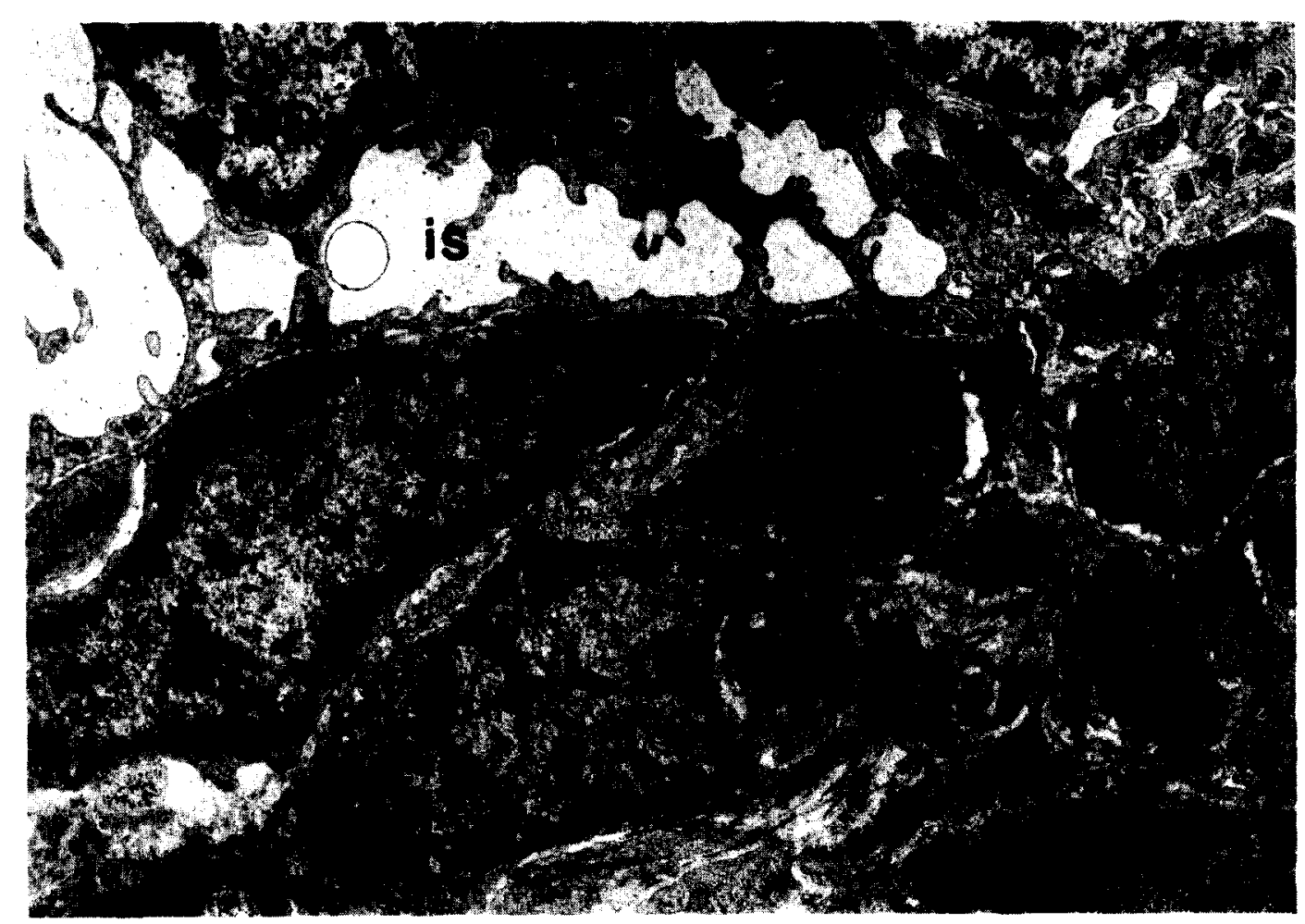

FIG. 6. Transmission electron micrograph exhibiting dilated intercellular space (is) between macula densa cells (MD) and polkissen cells $(P) . \times 3000$. 
precludes in situ direct study of the macula densa cells. Our laboratory has recently developed a technique in using the electron microprobe to quantitate sodium in single cells [7]. Utilizing this technique, we are able to quantitate sodium in the macula densa cell with accuracy. To obviate sodium diffusion, potassium pryoantimmoniate is added to the fixative. Formation of waterinsoluble sodium pryoantimmoniate precipitates sodium ions and circumvents the problem of sodium diffusion [4]. Sodium pryoantimmoniate precipitates appear as electron-dense granules in transmission electron micrographs (Fig. 4). Such granules are densely distributed along the basal lamina and the interstitial space (Fig. 5). Data from the electron microprobe quantitation of sodium can be converted to milliequivalents $\mathrm{Na}$ per kilogram tissue by using the biological standard that was developed in our laboratory [7]. The uniform distribution of sodium throughout the cytoplasm of the macula densa cells as depicted in Table 1 suggests that either sodium is a stable intracellular electrolyte or the mechanisms of maintaining intracellular homeostasis are ultraeffective or both. A constant intracellular sodium concentration in the face of the fluctuating plasma renin activity in different experimental settings is an unexpected finding. Although this observation does not lend support to the macula densa theory, neither does this finding preclude sodium from regulating renin secretion. It is possible that either sodium is transported across the macula densa cells very rapidly or it passes by these cells via the intercellular space. The presence of sodium pryoantimmoniate granules in the macula densa interstitium lends credence to this hypothesis (Figs. 4 and 5). It should be emphasized that renal tissue, perfusion-fixed under physiological pressure, displays dilated intercellular spaces (Fig. 6). Therefore, it is possible that dilated channels of communication exist between cells to provide free flow of the intercellular fluid.

Several pertinent findings emerge from the present study. There is no direct corre- lation between plasma renin activity and sodium concentration in macula densa cells to support the macula densa theory. In contradistinction, sodium is uniformly distributed throughout the macula densa cells. Results from our study do not support the tenet that alteration of the concentration of sodium in the macula densa cells regulates renin release. Somc other parametcrs must play a role.

\section{ACKNOWLEDGMENTS}

The authors wish to thank Miss Shirley Lim Sue for her technical assistance and Mrs. Martha M. M. Turner for typing the manuscript.

This work was supported by NSF Grant PCM8019709, and the Kidney Foundation of Michigan and the Michigan Heart Association.

\section{REFERENCES}

1. Blaine, E. H., and Davis, J. O. Evidence for a renal vascular receptor in the control of renin secretion. Amer. J. Physiol. 220: 1593, 1971.

2. Davis, J. O. What signals kidney to release renin? Circ. Res. 28: 301, 1971

3. Haber, E., Kawner, T., Page, L. B., Liman, B., and Purnode, A. Application of a radioimmunoassay for angiotensin $I$ to the physiologic measurements of plasma renin activity in normal human subjects. $J$. Clin. Endocrinol. 29: 1349, 1969.

4. Konick, H., and Konick, U. Elektronenmikroskopische untersuchungen zur funktionellen morphologie des ionentransportes in der salzdruse von larus argentatus. Z. Zellforsch 60: 163, 1963.

5. Skinner, S. L., McCubbin, J. W., and Page, I. H. Control of renin secretion. Circ. Res. 15: 64, 1964.

6. Sottiurai, V., and Malvin, R. L. The demonstration of cilia in macula densa cells. Amer. J. Anat. 135: $281,1972$.

7. Sottiurai, V. S., Malvin, R. L., Allard, L. F., and Bigelow, W. C. A biological standard for electron microprobe analysis or intracellular sodium concentration. J. Histochem. Cytochem. 24: 749, 1976.

8. Sottiurai, V. S., and Malvin, R. L. Polkissen cells and their possible role in renin secretion. Nephron 22: $558,1978$.

9. Tobian, L. Interrelationship of electrolytes, juxtaglomerular cells and hypertension. Physiol. Res. 40: $280,1960$.

10. Tobian, L. Relationship of the juxtaglomerular apparatus to renin and angiotensin. Circulation 25: $189,1962$.

11. Vander, A. J., and Miller, R. Control of renin secretion in the anesthetized dog. Amer. J. Physiol. 207: $537,1964$. 